J. Clin. Chem. Clin. Biochem.

Vol. 17, 1979, pp. 129-132

\title{
The Effect of Thioacetamide on Urea Cycle Enzymes ${ }^{1}$ ) of Rat Liver
}

\author{
By Maria Cascales, Blanca Feijóo, S. Cerdän, Carmen Cascales and A. Santos-Ruiz \\ Departamento de Bioquimica, Facultad de Farmacia, Universidad Complutense, Madrid
}

(Received June 2/November 23, 1978)

Summary: The urea cycle enzymes, carbamoyl-P-synthetase, ornithine transcarbamylase, arginase and other enzy.mes related to ammonia metabolism, such as glutamate dehydrogenase, glutamine synthetase and alanine and aspartate aminotransferases, have been studied in thioacetamide-induced liver disease in rats. Urea and ammonia were determined both in serum and in liver extracts. Glutamate and aspartate were determined in liver extracts.

There was a marked decrease (in brackets: fraction of control) in carbamoyl-P-synthetase (0.23), ornithine transcarbamylase (0.36) and arginase (0.62). The accumulation of ammonia (3.22) and the decreased urea level (0.80) are well known indications of liver failure.

Glutamate dehydrogenase and glutamine synthetase increased respectively to 1.50 and 1.33 , and the changes in glutamate and aspartate levels were respectively 1.68 and 0.92 ; this indicates that the metabolic route: 2-oxoglutarate $\rightarrow$ glutamate $\rightarrow$ glutamine is increased, and thereby compensates for the low rate of urea formation. Aminotransferase activities were respectively 0.43 and 0.25 . No significant differences were found in serum aminotransferases, or in the concentrations of ammonia and urea.

\section{Der Einfluß von Thioacetamid auf die Enzyme des Harnstoffcyclus in der Rattenleber}

Zusammenfassung: Die Enzyme des Harnstoffcyclus Carbamylphosphatsynthetase, Ornithintranscarbamylase sowie Arginase und die mit dem Ammoniakstoffwechsel verbundenen Enzyme Glutamatdehydrogenase, Glutaminsynthetase sowie Alanin- und Aspartataminotransferase wurden an Ratten mit durch Thioacetamid verursachter Lebererkrankung untersucht.

Harnstoff und Ammoniak wurden in Serum und Leberextrakten bestimmt, Glutamat und Aspartat nur in Leberextrakten. Die Ergebnisse zeigen einen deutlichen Abfall (in Klammern: relative Änderung, Kontrolle = 1,0) der Carbamylphosphatsynthetase $(0,23)$, Ornithintranscarbamylase $(0,36)$ und Arginase $(0,62)$. Die Zunahme von Ammoniak $(3,22)$ und die Abnahme von Harnstoff $(0,80)$ sind wohlbekannte Anzeichen für den Leberschaden.

Der Anstieg der Glutamatdehydrogenase und Glutaminsynthetase auf 1,50 bzw. 1,33 und die Veränderungen der Glutamat $(1,68)$ - und Aspartat $(0,92)$-Konzentration zeigen, daß der Stoffwechselweg: 2-Oxoglutarat $\rightarrow$ Glutamat $\rightarrow$ Glutamin die geringe Harnstoffbildung kompensiert. Relative Alanin- und Aspartataminotransferase-Aktivität betrugen 0,43 bzw. 0,25. Keịne signifikanten Unterschiede wurden für die Aminotransferasen sowie die Ammoniakund Harnstoffkonżentration im Serum gefunden.

1) Enzymes: Carbamoyl-P-synthetase, ATP: carbamate phosphotransferase (EC 2.7.2.5); Ornithine transcarbamylase, carbamoylphosphate- $L$-ornithine carbamoyltransferase (EC 2.1.3.3);

Arginase, $L$-arginine amidinohydrolase (EC 4.5.3.1);

Glutamate-oxaloacetate transaminase, $L$-aspartate: 2 -oxoglutarate aminotransferase (EC 2.6.1.1);

Glutamate-pyruvate transaminase, $L$-alanine: 2 -oxoglutarate aminotransferase (EC 2.6.1.2);

Glutamate dehydrogenase, $L$-glutamate: NAD oxidoreductase (deaminating) (EC 1.4.1.2);

Glutamine synthetase, $L$-glutamate: ammonia ligase (ADPforming) (EC 6.3.1.2).

\section{Introduction}

Since 1948 (1) thioacetamide has been widely studied. Most experiments have been carried out on the induction of hepatic necrosis, cirrhosis and tumours in rats. Schweitzer \& Schaetz' (2) reported that thioacetamideinduced cirrhosis resembles human cirrhosis more closely than other experimental forms. Rodriguez-Olleros et al., $(3,4)$ studied thioacetamide effects in dogs and they reported the development of atrophic cirrhosis. 
As the urea cycle represents an important detoxifying mechanism, the pattern of change in its intra- and extramitochondrial enzymes and metabolites is of interest for a better understanding of the effect of thioacetamide on liver metabolism. The metabolic significance of the urea cycle is well known as the main pathway for the removal of ammonia in ureotelic animals (5). There are, however, other routes for ammonia utilization, whereby ammonia is used to form metabolites such as glutamate and glutamine.

The present work attemps to study the changes of the urea cycle enzymes and those enzymes related to ammonia metabolism in rat liver, following thioacetamide administration. The knowledge thus gained may help in the understanding of the pathogenesis of liver diseases.

\section{Materials and Methods}

The chronic condition was induced by intraperitoneal administration of thioacetamide to male Wistar rats weighing 180 $220 \mathrm{~g}$. Thioacetamide-treated animals were injected for a period of 28-30 days with a freshly prepared solution of thioacetamide in saline $(\mathrm{NaCl} 0.15 \mathrm{~mol} / \mathrm{l})$ at a dose level of $50 \mathrm{mg} / \mathrm{d} \cdot \mathrm{kg}$ body weight. Controls received a similar volume of saline. From 4 to 8 animals were used for each experiment.

Ammonia dependent carbamoyl-P-synthetase was measured by the method of Chabas et al., (6) in the mitochondrial fraction obtained according to Grisolia \& Mendelson (7). Ornithine transcarbamylase was measured as described by Caravaca \& Grisolía (8) in the same fraction, while arginase was determined in the soluble fraction according to Schimke (9). Mitochondrial glutamate dehydrogenase was measured as described by Strecker (10), soluble aminotransferases were determined according to Bergmeyer \& Bernt $(11,12)$, and glutamine synthetase was determined by the procedure of Iqbal \& Ottaway (13) in the soluble fraction of essentially blood free liver homogenates. Liver homogenates were obtained in $0.25 \mathrm{~mol} / 1$ sucrose, $0.02 \mathrm{~mol} / \mathrm{l}$ Tris buffer $\mathrm{pH} 7.4$ and $0.1 \mathrm{mmol} / 1$ dithioerythritol in the proportion $1 \mathrm{~g}$ tissue: $4 \mathrm{ml}$ medium. All values are given as $\mu$ moles of substrate transformed per min measured at $37^{\circ} \mathrm{C}$ per $\mathrm{kg}$ of fresh liver or $\mathrm{l}$ of serum.

Urea, ammonia, glutamate and aspartate were determined in neutralized perchloric acid extracts of freeze clamped livers obtained as described by Lagunas et al., (14) and in serum. Urea was measured as ammonia after treatment with urease. Ammonia was determined spectrophotometrically with 2-oxoglutarate and glutamate dehydrogenase (glycerol suspension). Glutamate and aspartate were determined as described by Pfleiderer (15, $16)$. Values are given as $\mu$ moles per $\mathrm{kg}$ of fresh liver or 1 of serum.

Measurements were made on a Unicam SP-1800 spectrophotometer with a scale expansion unit. Results are expressed as means \pm S.E.M. Fisher's $\mathbf{P}$ values where $\mathbf{P}$ is greater than 0.05 are considered as not significant (N.S.).
Pyruvate kinase and lactate dehydrogenase were obtained from Sigma Chem Co. Other enzymes and nucleotides were obtained from Boehringer Mannheim GmbH (Mannheim Germany). All other biochemicals were obtained from Merck.

\section{Results}

As shown in table 1, the mitochondrial enzymes carbamoyl-P-synthetase and ornithine transcarbamylase decreased to a very low values: $0.23(\mathrm{p}<0.001)$ and $0.36(p<0.001)$, respectively. Also arginase decreased markedly to $0.62(\mathrm{p}<0.001)$ in the liver of thioacetamide-treated rats. These results, accompanied by an increase in the level of free ammonia to $3.22(\mathrm{p}<$ $0.001)$, and a decreased concentration of urea $(0.80$, $\mathrm{p}<0.01)$ in liver extracts of thioacetamide-treated rats (tab. 2), clearly demonstrate a significant disturbance in the urea cycle. Glutamate was increased to 1.64 ( $p<$ 0.05 ) and aspartate decreased slightly to 0.90 (N.S.) in liver extracts of thioacetamide treated rats.

In order to clarify the mechanism(s) of these changes, the activities of the main enzymes connected with the major flux of ammonia such as glutamate dehydrogenase, glutamine synthetase and alanine and aspartate aminotransferase were also determined. As can be seen in table 4, glutamate dehydrogenase was significantly higher in thioacetamide-treated rats than in the controls. Glutamate dehydrogenase was measured in the mitochondrial fraction and its increased activity was shown both for glutamate formation $(1,50, p<0.01)$ and for glutamate oxidation $(2.12, \mathrm{p}<0.001)$.

The increase of glutamine synthetase to 1.33 was not significant. Table 3 shows that in the thioacetamidetreated rats aspartate and alanine aminotransferase decreased to $0.43(\mathrm{p}<0.001)$ and $0.25(\mathrm{p}<0.001)$, respectively, when compared to the controls. The same enzyme activities in serum reveal a less consistent decrease to 0.91 and 0.90 for aspartate and alanine aminotransferases respectively.

\section{Discussion}

When testing metabolic disturbances produced by a toxic agent or a drug, the measurements of several enzymes linked in a metabolic cycle or chain are more revealing than those of an individual enzyme. The activity of the urea cycle in liver is interesting, particularly because of the different location of the enzymes of this

Tab. 1. Enzymes of the urea cycle in thioacetamide-treated rat liver.

\begin{tabular}{|c|c|c|c|c|}
\hline Enzyme & $\begin{array}{l}\text { Control } \\
(\mathrm{kU} / \mathrm{kg})\end{array}$ & $\begin{array}{l}\text { Thioacetamide } \\
\text { (kU/kg) }\end{array}$ & Fraction & $\mathrm{p}<$ \\
\hline $\begin{array}{l}\text { Carbamoyl-P synthetase } \\
\text { Ornithine transcarbamylase } \\
\text { Arginase }\end{array}$ & $\begin{aligned} 2.33 & \pm 0.07(4) \\
136.8 & \pm 24.4(4) \\
1749 & \pm 104\end{aligned}$ & $\begin{aligned} 0.54 & \pm 0.17(4) \\
49.3 & \pm 5.6(4) \\
1093 . & \pm 136 \quad(8)\end{aligned}$ & $\begin{array}{l}0.23 \\
0.36 \\
0,62\end{array}$ & $\begin{array}{l}0.001 \\
0.001 \\
0.001\end{array}$ \\
\hline
\end{tabular}

Values are expressed as $\mathrm{kU} / \mathrm{kg}$ of fresh liver. A unit is defined as the amount catalysing the formation of $1 \mu$ mol of product per min at $37^{\circ} \mathrm{C}$.

Figures in parenthesis are the number of experimental observations. Results are given as means \pm S.E.M. . . 
Tab. 2. Free ammonia, urea, glutamate and aspartate in serum and in liver extracts in thioacetamide-treated rats.

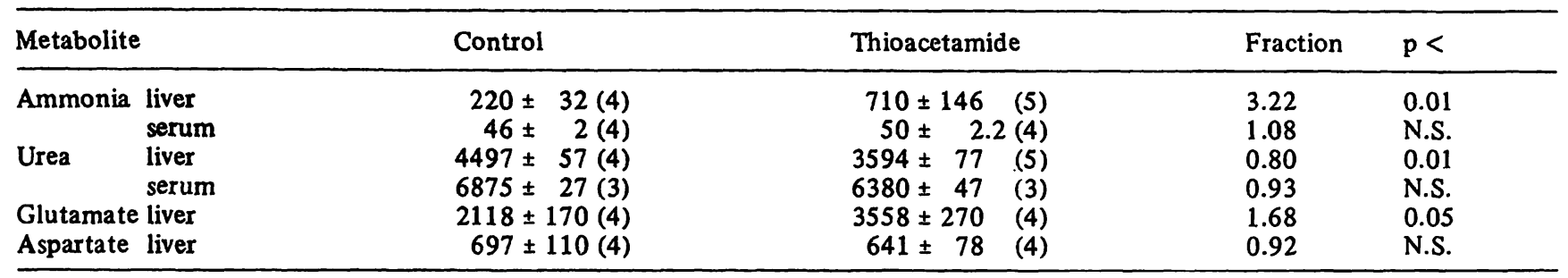

Values are expressed as $\mu \mathrm{mol} / \mathrm{kg}$ of fresh liver or $\mu \mathrm{mol} / \mathrm{l}$ of serum. Figures in parenthesis are the number of experimental observations. Results are given as means \pm S.E.M.

Tab. 3. Effect of thioacetamide on the aminotransferases in rat liver and serum.

\begin{tabular}{llcccc}
\hline Enzyme & Control & Thioacetamide & Fraction & $p<$ \\
\hline Aspartate aminotransferase serum & $0.051 \pm 0.007$ & $0.046 \pm 0.006$ & 0.91 & N.S. \\
& liver & $52.9 \pm 5.4$ & $22.8 \pm 2.3$ & 0.43 & 0.001 \\
Alanine aminotransferase & serum & $0.017 \pm 0.001$ & $0.015 \pm 0.003$ & 0.90 & N.S. \\
& liver & $26.7 \quad \pm 1.92$ & $6.8 \pm 0.95$ & 0.25 & 0.001 \\
\hline
\end{tabular}

Values are expressed as $\mathrm{kU} / \mathrm{kg}$ of fresh liver or $\mathrm{kU} / \mathrm{l}$ of serum. A unit is defined as the amount catalysing the formation of $1 \mu \mathrm{mol}$ of product per min at $37^{\circ} \mathrm{C}$.

Results are given as means of six animals \pm S.E.M.

cycle. Carbamoyl-P-synthetase and ornithine transcarbamylase are mitochondrial enzymes, while the remainder are located in the cytosol (17).

Liver extracts from rats intoxicated by thioacetamide showed a lower level of urea than that observed in control animals. A considerable decrease in carbamoyl-P. synthetase, ornithine transcarbamylase and arginase was observed in thioacetamide-treated animals. Moreover, thioacetamide treatment produced a high ammonia concentration, accompanied by an increase in glutamate dehydrogenase activity and in the concentration of glutamate. These altered values seem to show that one effect of thioacetamide liver toxicity is to produce a decrease in the flux of urea formation and a marked accumulation of ammonia, both recognized symptoms of liver failure.

Amino groups from various amino acids are first transferred to 2-oxoglutarate to yield glutamate, and the glutamate pool is the main nitrogen donor to urea cycle, either as aspartate or as ammonia. Under normal conditions about 0.90 of the oxidized glutamate is converted to aspartate (via aspärtate aminotransferase) and only 0.10 is converted to ammonia (via glutamate dehy- drogenase) $(17,18)$. The decreased level in aspartate aminotransferase activity and the enhanced activity of glutamate dehydrogenase in thioacetamide treated liver is probably a consequence of the increased ammonia concentration.

It is well known that ammonia increases under certain circumstances such as high protein diet, diabetes, etc.; the urea cycle functions like a regulatory mechanism, increasing its activity and consequently maintaining the intracellular ammonia at a normal level. By this mechanism the cell protects itself from the toxic effect of ammonia accumulation. There are two main mechanisms for the elimination of ammonia: the urea cycle and the formation of glutamine via glutamate dehydrogenase and glutamine synthetase. The urea cycle is inhibited in thioacetamide-treated rats, and there is consequently an increase of ammonia; this inhibits 2-oxoglutarate formation (19). In spite of the fact that glutamate dehydrogenase is increased (see tab. 4), glutamate formation is limited by the low concentration of 2-oxoglutarate. Therefore, as ammonia increases 2 -oxoglutarate decreases and the glutamate dehydrogenase is not able to remove the ammonia by the reductive biosynthesis of glutamate.

Tab. 4. Effect of thioacetamide on glutamate dehydrogenase and glutamine synthetase.

\begin{tabular}{|c|c|c|c|c|}
\hline Enzyme & Control & Thioacetamide & Fraction & $\mathrm{p}<$ \\
\hline $\begin{array}{l}\text { Glutamate dehydrogenase NADH* } \\
\text { NAD** } \\
\text { Glutamine synthetase }\end{array}$ & $\begin{array}{l}26.8 \pm 4.3(4) \\
0.81 \pm 0.22(4) \\
2.17 \pm 0.43(3)\end{array}$ & $\begin{aligned} 40.2 & \pm 4.1(4) \\
1.72 & \pm 0.28(4) \\
2.89 & \pm 0.22(3)\end{aligned}$ & $\begin{array}{l}1.50 \\
2.12 \\
1.33\end{array}$ & $\begin{array}{l}0.01 \\
0.001 \\
\text { N.S. }\end{array}$ \\
\hline
\end{tabular}

Values are expressed as $\mathrm{kU} / \mathrm{kg}$ of fresh liver. A unit of enzyme is defined as the amount catalysing the formation of $1 \mu \mathrm{mol}$ of product per min at $37^{\circ} \mathrm{C}$.

* glutamate formation.

** 2-oxoglutarate and ammonia formation. Figures in parenthesis are the number of experimental observations. Results are given as means \pm S.E.M. 
Aminotransferases are linked to the urea cycle. The conversion of glutamate to aspartate provides half of the urea nitrogen that enters the urea cycle as aspartate. In the extramitochondrial area, oxidation of malate or transamination of aspartate yield oxaloacetate. When soluble aspartate aminotransferase decreases, as in the case of thioacetamide-treated rats, the oxaloacetate pool becomes lower, but availability of aspartate for urea synthesis is not significantly affected. The degree of involvement of aspartate aminotransferase, alanine aminotransferase and glutamate dehydrogenase in urea synthesis depends on the level of urea precursors.

\section{References}

1. Fitzhugh, D. H. \& Nelson, A. A. (1948), Science 108, 626-631.

2. Schweitzer, C. H. \& Schaetz, G. (1957), in Pathologie, Diagnostik und Therapie der Leberkrankheiten. 40. Freiburger Symposion, pp. 166-171, Springer Verlag, BerlinHeidelberg-New York.

3. Rodriguez-Olleros, A., Taveras, J. E. \& Anglade-Delanoy, A. (1968), Scand. J. Gastroenterol. 3, 65-75.

4. Rodriguez-Olleros, A., Taveras, J. E., Irizarri, S. \& LandronBecerra, F. M. T. (1969), Am. J. Gastroenterol. 52, 127 140.

5. Krebs, H. A., Hems, R. \& Lund, P. (1973), Biochem. J. 134, 697-705.

6. Chabas, A., Grisolía, S. \& Silverstein, R. (1972), Eur. J. Biochem. 29, 333-342.

7. Grisolía, S. \& Mendelson, J. (1972), Biochem. Biophys. Res. Commun. 58, 968-973.

8. Caravaca, J. \& Grisolía, S. (1960), J. Biol. Chem. 235, 684693.

9. Schimke, R. T. (1970), Methods in Enzymology XVIIa, 313-317.

10. Strecker, H. J. (1953), Arch. Biochem. Biophys. 46, 128140.
These findings, particularly the rise in glutamate dehydrogenase activity when the urea cycle is inhibited, provide new evidence on the regulatory mechanism involved in the control of ammonia metabolism in the liver under pathological conditions.

\section{Acknowledgements}

We thank Miss Dolores Velasco for her technical assistance. This work was supported by a grant from ALTË $\vec{R}$ S.A.
11. Bergmeyer, H. U. \& Bernt, E. (1965), in Methods of Enzymätic Analysis (Bergmeyer, H. U., ed.) pp. 837-842, Academic Press.

12. Bergmeyer, H. U. \& Bernt, E. (1965) in Methods of Enzymatic Analysis (Bergmeyer, H. U., ed.) pp. 846-851. Academic Press.

13. Iqbal, K. \& Ottaway, J. H. (1970), Biochem. J. 119, 145156.

14. Lagunas, R., McLean, P. \& Greenbaum, A. L. (1970), Eur. J. Biochem. 15, 179-190.

15. Pfleiderer, G. (1965), in Methods of Enzymatic Analysis (Bergmeyer, H. U., ed.) pp. 394-397, Academic Press.

16. Pfleiderer, G. (1965), in Methods of Enzymatic Analysis (Bergmeyer, H. U., ed.) pp. 381-383.

17. Lowenstein, J. M. (1972), Physiol. Rev. 52, 382-414.

18. Sallach, H. J. \& Fahien, L. A. (1969), in Metabolic Pathways III, 3rd ed. (Greenberg, D. M., ed.) pp. 1-94. Academic Press, London.

19. Katunuma, N., Okada, M. \& Nishii, Y. (1966), Adv. Enzyme Regul. 4, 317-335.
Dr. Maria Cascales Facultad de Farmacia Departamento de Bioquimica Ciudad Universitaria Madrid 3 Spain 


\section{Glucocorticoid}

\section{Hormone Action}

\section{Edited by}

\section{J.D. Baxter and G.G. Rousseau}

1979. 176 figures, 58 tables. Approx. 700 pages

(Monographs on Endocrinology, Vol 12)

Cloth DM 118,-; US \$ 64.90

ISBN 3-540-08973-X

Prices are subject to change without notice

This is the most up-to-date and scholarly treatment available of the molecular mechanisms governing the action of glucocorticoid hormones. The book, dedicated to the late Gordon Tomkins, is written by active researchers in the field and contains a wealth of hitherto unpublished material.

A number of selected topics are analyzed, from immunosuppression and effects on the central nervous system to the mechanisms of receptor function and regulation of viral mRNA. Model systems are presented illustrating important aspects of the mechanism of glucocorticoid hormones. A discussion of glucocorticoid physiology provides a useful perspective.

Important as models for understanding gene regulation and hormone action in general, glucocorticoids are one of the most widely used pharmacological agents. This study will, therefore, appeal to clinicians, molecular biologists, physiologists and pharmacologists. GLUCOCOTICOID HORMONE ACTION will long be regarded as a landmark publication on this area of research.



Springer-Verlag Berlin Heidelberg New York

\section{Elektrofokussierung Disc-Elektrophorese}

sowie alle weiteren Varianten der

FlachgelElektrophorese

z.B. in Acrylamid etc. lassen sich mit diesem System problemlos und reproduzierbar ausführen.

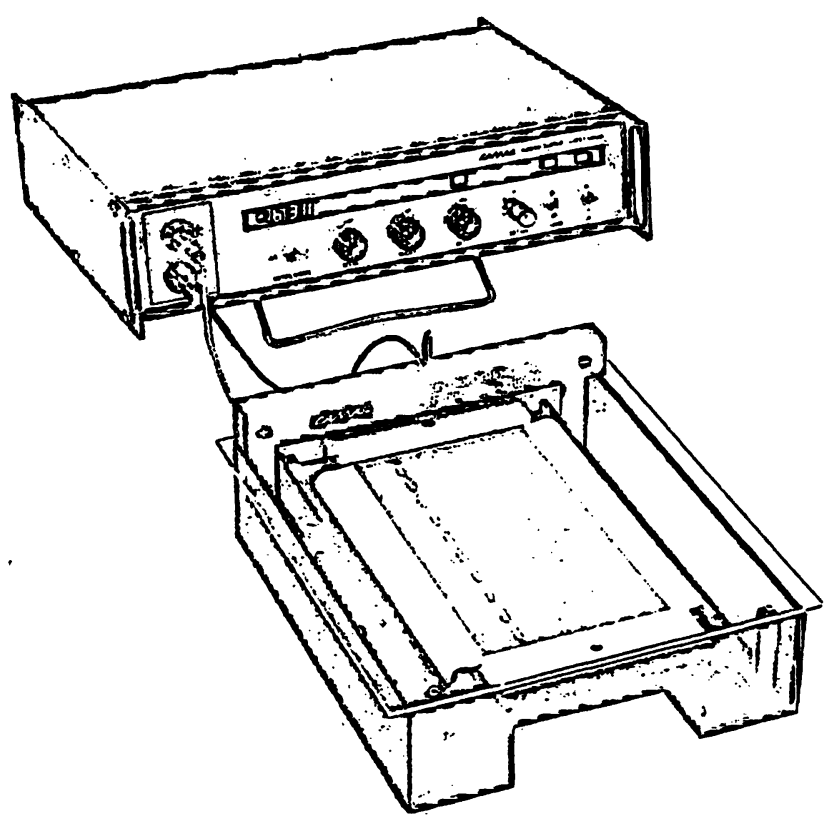

Die Kammer:

- Arbeitsfläche $120 \times 200 \mathrm{~mm}$

- Schichtdicken bis $5 \mathrm{~mm}$

- Wirksàmẹ Wàsserkühlựng für schnelle Trennụngen

- Ein komplettes System mit durchdachtem, reichhaltigem Zubehörr erlaubt die Auśführung horizontaler und vèrtikaler Giesstechniken - direkt in der Kammer

\section{Das Gleichspannungs-Speisegerăt:}

- Spannung. Strom und Leistung stabilisiert

- Gleichspannung kontinuierlich regelbar bis $1000 \mathrm{~V}, 100 \mathrm{~mA}$

- Messanzeige digital

- CAMAG Sicherheitssystem für ungefährdetes Arbeiten

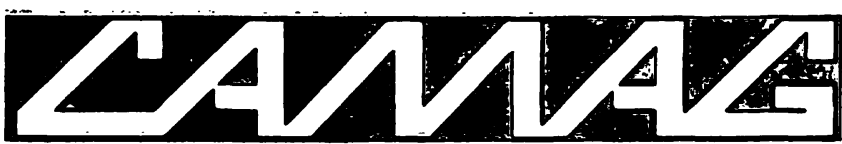

Homburgerstrasse 24 4132 Muttenz/Schweiz Tel. (061) 613434
Bismarckstrasse 27-29 1000 Berlin 41 Tel. (030) 7951091 


\section{Lieferanten-Nachweis}

\section{- Autoklaven}

HEINICKE INSTRUMENTS

Laborgerätebau $\mathrm{GmbH}$

8225 Traunreut, Pf 1250

Ruf $08669 / 4049$, FS 05-6556

- Bakteriologie

OTTO NORDI:ALD KE

2000 Hamburg 50, Heinrichstr. 5

Ruf $040 / 432827$

- Brutschränke

HEINICKE INSTRUMENTS

Laborgerätebau $\mathrm{GmbH}$

8225 Traunreut, $P f 1250$

Ruf 086 69/40 49, FS 05.6556

- Chromatographie-Pumpen VERDER (DEUTSCHLAND) GMBH 4000 Düsseldort, Luegallee 108

Ruf $0211 / 574079$

FS: 08585539

- Digitale Verdünnungsgeräte

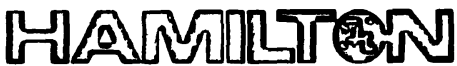

Hamilton Deutschland $\mathrm{GmbH}$

Postfach 110427

Otto-Röhm-Str. 74

D-6100 Darmstadt

Ruf $06151 / 85085-86$, FS 0419684

- Digitale Dispensiergeräte

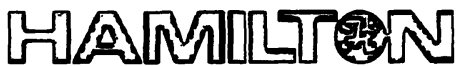

Hamilton Deutschland GmbH

Postfach 110427

Otto-Röhm-Str. 74

D-6100 Darmstadt

Ruf $06151 / 85085-86$, FS 0419684

- Elektrophorese

CARL ZEISS

7082 Oberkochen, Pf. 1369

- Filterphotometer

CARL ZEISS

7082 Oberkochen, Pf. 1369

- Flammenphotometer CARL ZEISS

7082 Oberkochen, Pf. 1369

- Gasdichte Spritzen

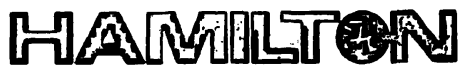

Hamilton Deutschland $\mathrm{GmbH}$

Postfach 110427

Otto-Röhm-Str. 74

D-6100 Darmstadt

Ruf $06151 / 85085-86$, FS 0419684
- Infrarot-Spektralphotometer CARL ZEISS

7082 Oberkochen, Pf. 1369

- Klinische Reagenzien

TT PIERCE EUROCHEMIE B.V. P O BOX IIS1-ROTTERDAM THE NETHERLANOS

\section{- Küvetten}

HELLMA GMBH \& CO.

7840 Müllheim/Baden

Ruf $07631 / 5509$ und 5500 FS 0772987

- Küvetten-Absaugpumpen HELLMA GMBH \& CO

7840 Mullheim/Baden

Ruf $07631 / 5509$ und 5500 FS 0772987

- Küvetten-Reinigungsmittel HELLMA GMBH \& CO.

7840 Müllheim/Baden

Ruf $07631 / 5509$ und 5500 FS 0772987

- Küvetten-Ständer HELLLMA GMBH \& CO. 7840 Mullheim/Baden

Ruf $07631 / 5509$ und 5500 FS 0772987

- Küvetten-Trockenschleudern

HELLMA GMBH \& CO.

7840 Müllheim/Baden

Ruf $07631 / 5509$ und 5500 FS 0772987

\section{- Laborspülmittel}

deconex ${ }^{\circledR}$

das umfassende Reinigungsprogramm für Labors aller Bereiche

BORER CHEMIE AG

Zürcher Str. 125

Postfach 352

CH-8952 Schlieren-Zürich

Ruf (01) 7301535

Telex CH 54031 SPONA

\section{- Microliterspritzen ${ }^{\circledR}$

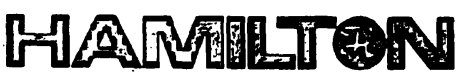

Hamilton Deutschland $\mathrm{GmbH}$

Postfach 110427

Otto-Röhm-Str. 74

D-6100 Darmstadt

Ruf 061 51/850 85-86, FS 0419684

\section{- Mikroskope}

HERTEL \& REUSS

3500 Kassel, Quellhofstr. 67

Ruf $0561 / 83006$

WILL WETZLAR KG

Optische Werke

Postfach 40

6331 Nauborn-Wetzlar

Ruf $06441 / 23071.4$

CARL ZEISS

7082 Oberkochen, Pf. 1369
pH-Meßgeräte + pH-Glaselektroden

INGOLD pH-Meßtechnik 6000 . Frankfurt 1

Postf. 3308, Ruf 06 11/29 5301

\section{- Photometer}

CARL ZEISS

7082 Oberkochen, Pf. 1369

- Polarimeter

CARL ZEISS

7082 Oberkochen, Pf. 1369

\section{- Radioaktive Stoffe}

AMERSHAM BUCHLER

3300 Braunschweig, Postf. 1120

Ruf 053 07/46 93-97

\section{- Reinigungsmittel}

deconex ${ }^{\circledR}$

das umfassende Reinigungspro.

grạmm für Labors aller Bereiche

BORER CHËMIË AG

Zürcher Str. 125

Postfach 352

CH-89́52 Schlieren-Zürich

Ruf (01) 7301535

Telex CH 54031 SPONA

\section{- Spektralphotometer}

CARL ZEISS

7082 Oberkochen, Pf. 1369

\section{- Schlauchpumpen}

VERDER (DEUTSCHLAND) GMBH 4000 Düsseldorf, Luegallee 108

Ruf 02 11/57 40 79, FS: 08585539

\section{- Sterilisierpapiere}

J.C. BINZER

3559 Hatzfeld

Ruf $06467 / 3$ 18, FS: 0482224

\section{Trockenschränke}

HEINICKE INSTRUMENTS

Laborgerätebau $\mathrm{GmbH}$

8225 Traunreut, Pf 1250

Ruf $08669 / 40$ 19, FS 05-6556

\section{Waschautomaten für} Laborglas

HEINICKE INSTRUMENTS

Laborgerätebau $\mathrm{GmbH}$

8225 Traunreut, Pf 1250

Ruf $08669 / 4049$, FS 05-6556

\section{- Zentrifugen}

BERTTHOLD HERMLE KG

7209 Gosheim, Postfach 1240.

Ruf 074 26/ 1061 